\title{
A study of demographic variables of violent asphyxial deaths in Agra region
}

\author{
Tarun Kumar Singh ${ }^{1}$, Ajay Agarwal ${ }^{2}$, Richa Gupta ${ }^{3, *}$, Vaibhav Sharma ${ }^{4}$ \\ ${ }^{1}$ Tutor, ${ }^{2}$ Professor and Head, ${ }^{3}$ Assistant Professor, ${ }^{4}$ Lecturer, Dept. of Forensic Medicine and Toxicology, S.N. Medical College, Agra, \\ Uttar Pradesh, India
}

${ }^{*}$ Corresponding Author: Richa Gupta

Email: drrichag79@gmail.com

\begin{abstract}
Introduction: In our world, many human lives are lost to crime and violence in which asphyxial deaths are one of the major contributors. Materials and Methods: In present study analysis of 391 deaths caused by asphyxia out of 3224 autopsies conducted in mortuary of S. N. Medical College, Agra during period of 11/2 years from March 2015 to August 2016 is conducted. Data obtained is reviewed and analyzed according to different types of asphyxial deaths, their age wise distribution, sex wise distribution, manner of death and contributing factors. Results: Proportion of asphyxial deaths was $12.1 \%$ (391 cases). Hanging (64.9\%) is most commonly encountered followed by drowning $(24.8 \%)$ and strangulation (4.6\%). Most common victims are male with male: female ratio of 1.37: 1. Most cases falls in 21-30 years age group with $27.4 \%$ of total. Majority of hanging cases were suicidal while all strangulation cases were homicidal. Majority of drowning cases were accidental. It was elicited from history that personal reasons like failure in examinations, psychiatric problems, long time illness etc. were the most common reasons for suicide by hanging.

Conclusion: In present study, suicidal hanging and accidental drowning seems to be major proportions of violent asphyxial deaths. Both these manners of deaths indicate frustration and carelessness on part of population which are preventable and needs to be rectified on urgent basis.
\end{abstract}

Keywords: Asphyxia, Hanging, Strangulation, Drowning.

\section{Introduction}

Asphyxia is almost exactly a trans- Literation from the Greek asphuxia, the Greek upsilon being replaced as is customary by our English "y." The word which has now come to mean a shutting-off of the breath meant in the original Greek a stoppage of the pulse. It was noted from very early times that any incident which shut off the breathing very soon caused a stoppage of the pulse and of the heartbeat. "The term asphyxia is defined as a condition caused by interference with respiration or due to lack of $\mathrm{O}_{2}$ in respired air due to which the organs and tissues are deprived of $\mathrm{O}_{2}$ (together with failure to eliminate $\mathrm{CO}_{2}$ ), causing unconsciousness or death". It is the common endpoint in a variety of deaths in which the cells either fail to receive, or are unable to utilize, oxygen. ${ }^{1}$ Asphyxial deaths are regularly encountered during forensic practices, therefore it is of utmost importance to determine manner of asphyxial deaths to understand underlying root causes.

In India, population has increased very rapidly resulting in poverty. Also, our daily life has become more stressful. Because of these factors cases of suicides, homicides and accidents due to violent asphyxia have become more and more common. According to the NCRB, suicide is among top ten causes of overall deaths in India in all age groups while among top three in 15 to 45 years' age group. According to NCRB-2013 statistics, among the methods chosen for suicidal purposes, Hanging, is most common $(39.8 \%)$, drowning being 4th $(5.7 \%)$. For Homicidal purposes, Asphyxiation by Strangulation \& Smothering is 3rd most commonly chosen method. ${ }^{2}$

In present study an attempt has been made to analyze various trends and factors associated with the violent asphyxial deaths in Agra region so that further insight into the existing knowledge related to the subject can be gained with the view to assist the process of crime investigation and proper utilization of resources.

\section{Materials and Methods}

The present study is carried out in the department of Forensic Medicine and Toxicology, S. N. Medical College, Agra from March 2015 to august 2016 for a period of one and half year. A total of 3224 autopsies were carried out during this period. Out of them 391 cases of violent asphyxial deaths were included and reviewed in study. Each and every case examined as per predesigned and pretested proforma, the data is then scrutinized with the help of statistician and presented in different tables to highlight the facts from various aspects of study. In present study various types of asphyxial deaths, their age wise distribution, sex wise distribution, manner of death and contributing factors are studied.

\section{Result}

Proportion of violent asphyxia deaths was $12.1 \%$ (391 cases) of total 3224 autopsies in the present study. (Table 1)

Hanging (64.9\% - 254 cases) is the most commonly encountered violent asphyxia death followed by drowning $(24.8 \%$ - 97 cases $)$ and strangulation $(4.6 \%$ - 18 cases $)$. (Table 2)

Males are more common victims with male: female ratio of 1.37: 1. Males predominate both in hanging and drowning. (Table 3)

Most commonly involved age group is $21-30$ years (107 cases forming $27.4 \%$ of total) followed by 11-20 years' age group ( 75 cases forming $19.2 \%$ of total). (Table 4 )

From all the cases of hanging, majorities $(98 \%)$ were suicidal and a few were accidental $(1.2 \%)$ and Homicidal $(0.8 \%)$. All 18 strangulation cases were of homicide. 64 out 
of $97(66 \%)$ cases of drowning were accidental and remaining $29(29.9 \%)$ were suicidal and 4 (4.1\%) were homicidal. (Table 5)

It was elicited from the history that personal reasons (136 out of 254 cases) like failure in the examinations, psychiatric problems, long time illness etc. were the most common reasons for suicide by hanging followed by family/domestic problems (41 cases), borrowings (23 cases) and extra-marital affairs ( 7 cases). (Table 6)

Table 1: Proportion of violent asphyxial death cases

\begin{tabular}{|l|c|}
\hline Total no. of autopsies from March 2015 to August 2016 & 3224 \\
\hline No. of violent asphyxial deaths from March 2015 to August 2016 & 391 \\
\hline Percentage of violent asphyxial deaths & $12.1 \%$ \\
\hline
\end{tabular}

Table 2: Case wise proportion of violent asphyxial death cases

\begin{tabular}{|l|c|c|}
\hline \multicolumn{1}{|c|}{ Cause of death } & N & \% \\
\hline Hanging & 254 & 64.9 \\
\hline Drowning & 97 & 24.8 \\
\hline Strangulation & 18 & 4.6 \\
\hline Others & 22 & 5.7 \\
\hline Total & 391 & 100 \\
\hline
\end{tabular}

Table 3: Sex wise distribution of violent asphyxial death cases

\begin{tabular}{|l|c|c|c|c|}
\hline \multirow{2}{*}{ Cause of death } & \multicolumn{2}{|c|}{ Male } & \multicolumn{2}{c|}{ Female } \\
\cline { 2 - 5 } & $\mathbf{N}$ & $\mathbf{\%}$ & $\mathbf{N}$ & $\mathbf{\%}$ \\
\hline Hanging & 137 & 53.9 & 117 & 46.1 \\
\hline Drowning & 62 & 63.9 & 35 & 36.1 \\
\hline Strangulation & 11 & 61.1 & 7 & 38.9 \\
\hline Others & 16 & 72.7 & 6 & 27.3 \\
\hline Total & 226 & 57.8 & 165 & 42.2 \\
\hline
\end{tabular}

Table 4: Age wise distribution of violent asphyxial death cases

\begin{tabular}{|c|c|c|c|c|c|c|c|c|c|}
\hline \multirow{2}{*}{$\begin{array}{c}\text { Age } \\
\text { Group }\end{array}$} & \multicolumn{2}{|c|}{ Hanging } & \multicolumn{2}{c|}{ Drowning } & \multicolumn{2}{c|}{ Strangulation } & \multicolumn{2}{c|}{ Others } & \multicolumn{2}{c|}{ Total } \\
\cline { 2 - 10 } & $\mathbf{N}$ & $\mathbf{\%}$ & $\mathbf{N}$ & $\mathbf{\%}$ & $\mathbf{N}$ & $\mathbf{\%}$ & $\mathbf{N}$ & $\mathbf{\%}$ & $\mathrm{N}(\%)$ \\
\hline $0-10$ & 00 & 00 & 7 & 7.2 & 00 & 00 & 1 & 4.5 & $8(2.0)$ \\
\hline $11-20$ & 58 & 22.8 & 19 & 19.6 & 2 & 11.1 & 6 & 27.3 & $85(21.7)$ \\
\hline $21-30$ & 96 & 37.8 & 21 & 21.6 & 5 & 27.8 & 3 & 13.6 & $125(32.0)$ \\
\hline $31-40$ & 48 & 18.9 & 11 & 11.3 & 7 & 38.9 & 5 & 22.8 & $71(18.2)$ \\
\hline $41-50$ & 23 & 9.1 & 12 & 12.4 & 3 & 16.7 & 2 & 9.1 & $40(10.2)$ \\
\hline $51-60$ & 18 & 7.1 & 18 & 18.5 & 1 & 5.5 & 3 & 13.6 & $40(10.2)$ \\
\hline$>60$ & 11 & 4.3 & 9 & 9.3 & 00 & 00 & 2 & 9.1 & $22(5.6)$ \\
\hline Total & 254 & 100 & 97 & 100 & 18 & 100 & 22 & 100 & $391(100)$ \\
\hline
\end{tabular}

Table 5: Manner of death

\begin{tabular}{|l|c|c|c|c|c|c|c|c|}
\hline \multirow{2}{*}{ Cause of Death } & \multicolumn{2}{|c|}{ Suicidal } & \multicolumn{2}{c|}{ Homicidal } & \multicolumn{2}{c|}{ Accidental } & \multicolumn{2}{c|}{ Total } \\
\cline { 2 - 9 } & $\mathbf{N}$ & $\mathbf{\%}$ & $\mathbf{N}$ & $\mathbf{\%}$ & $\mathbf{N}$ & $\mathbf{\%}$ & $\mathbf{N}$ & \% \\
\hline Hanging & 249 & 98 & 2 & 0.8 & 3 & 1.2 & 254 & 100 \\
\hline Drowning & 29 & 29.9 & 4 & 4.1 & 64 & 66 & 97 & 100 \\
\hline Strangulation & 00 & 00 & 18 & 100 & 00 & 00 & 18 & 100 \\
\hline Others & 00 & 00 & 7 & 31.8 & 15 & 68.2 & 22 & 100 \\
\hline Total & 278 & 71 & 31 & 8 & 82 & 21 & 391 & 100 \\
\hline
\end{tabular}

Table 6: Contributing factors for death

\begin{tabular}{|l|c|c|c|c|c|c|c|c|c|}
\hline \multirow{2}{*}{ Reason for Death } & \multicolumn{2}{c|}{ Hanging } & \multicolumn{2}{c|}{ Strangulation } & \multicolumn{2}{c|}{ Drowning } & \multicolumn{2}{c|}{ Others } & Total \\
\cline { 2 - 10 } & $\mathbf{N}$ & $\mathbf{\%}$ & $\mathbf{N}$ & $\mathbf{\%}$ & $\mathbf{N}$ & $\mathbf{\%}$ & $\mathbf{N}$ & $\boldsymbol{\%}$ & $\mathrm{N}(\%)$ \\
\hline Personal & 136 & 53.5 & 00 & 00 & 00 & 00 & 00 & 00 & $136(34.8)$ \\
\hline Social/family problems & 41 & 16.1 & 00 & 00 & 13 & 13.4 & 00 & 00 & $54(13.8)$ \\
\hline Borrowings & 23 & 9.1 & 00 & 00 & 00 & 00 & 00 & 00 & $23(5.9)$ \\
\hline Extramarital affairs & 7 & 2.8 & 00 & 00 & 00 & 00 & 00 & 00 & $7(1.8)$ \\
\hline
\end{tabular}




\begin{tabular}{|l|c|c|c|c|c|c|c|c|c|}
\hline Revenge & 00 & 00 & 6 & 33.3 & 00 & 00 & 00 & 00 & $6(1.5)$ \\
\hline Not known & 44 & 17.3 & 12 & 66.7 & 20 & 20.6 & 7 & 31.8 & $83(21.2)$ \\
\hline Accidental & 3 & 1.2 & 00 & 00 & 64 & 66 & 15 & 68.2 & $82(21)$ \\
\hline Total & 254 & 100 & 18 & 100 & 97 & 100 & 22 & 100 & $391(100)$ \\
\hline
\end{tabular}

\section{Discussion}

In medico-legal autopsies of violent death cases a large number include death due to asphyxia as one of the most important cause. In the present study during the one and half year from March 2015 to August 2016 total 3224 autopsies were conducted at the mortuary of S.N. Medical College, Agra in which proportion of asphyxia deaths is found to be $12.1 \%$ (391 cases). This proportion is lower than the studies by AzmakD (15.7\%) and Gurudut KS et al (14.5\%), but higher than studies by Amandeep et al $(5.26 \%)$ and by Patel Ankur $\mathrm{P}$ et al $(5.63 \%))^{3-6}$ Further, this proportion is similar to the studies by Gupta Ved Prakash, Mahanta P (11.54\%) and Lalwani $S$ et al $(11.21 \%))^{7-8}$ The reason for variation in the proportion of asphyxial deaths may be due to cultural and ethnic difference.

In present study hanging (64.9\%) is the most commonly adopted method of violent asphyxia followed by drowning (24.8\%) amongst the people of Agra. It is well known fact that Indian legislation has also accepted hanging as the means for judicial execution of death sentence, as judicial hanging is considered painless mode of death.

Hanging is noticed to be the most common type of violent asphyxial deaths by all the authors except Amandeep et al, who has explained the proximity of "bhakhra canal" in his region for higher incidence of deaths due to drowning. ${ }^{5}$

Incidence rate of hanging in study by Patel Ankur P et al was $82.48 \%$, in study by Gurudut KS, et al was $61.16 \%$, in study by Azmak D was $41.8 \%$ and in study by Gupta Ved Prakash, Mahanta P was $78.12 \%{ }^{3,4,6,7}$

Incidence rate of drowning also varies in different studies.

The difference in the incidence rate of different violent asphyxia death is because the type of death adopted by people is dependent on the intrinsic peculiarities of population and culture.

Most common victims are male with male: female ratio of $1.37: 1$. In both hanging and drowning males are predominant as females commonly opt poison intake and burning as methods of suicide. These results are consistent with results of Srinivassa Reddy P et al (Male: Female ratio - 1.4: 1) and Chaurasia $\mathrm{N}$ et al (Male: Female ratio - 1.5: 1). ${ }^{9-10}$

21-30 years' age group is most commonly affected group (125 cases forming $32.0 \%$ of total) followed by $11-20$ years' age group ( 85 cases forming $21.7 \%$ of total). This young adult group is most active group of population and more exposed to external environment and stress and strain of life. These findings are consistent with findings of other studies conducted by Gupta Ved Prakash, Mahanta P, Chaurasia $\mathrm{N}$ et al and Patel Ankur P et al. 6,7,10

Homicidal hangings are generally thought to be highly unusual as manner of death in hanging is virtually always considered suicidal and in strangulation homicidal. Accidental hanging does occur sometimes. However, some cases of homicidal hangings are reported, according to retrospective study by Azmak D (Turkey) homicidal hangings are very much uncommon. ${ }^{3}$ However, study by Gambhir Singh et al has described some homicidal hangings. ${ }^{11}$

All 18 strangulation cases were of homicide, 64 out of $97(66 \%)$ cases of drowning were accidental and remaining $29(29.9 \%)$ were suicidal and $4(4.1 \%)$ were homicidal. Overall most cases were suicidal ( 278 cases forming $71 \%$ of total) followed by accidental ( 82 cases forming $21 \%$ of total) and homicidal (31 cases forming $8 \%$ of total).

Personal reasons were most commonly attributed to suicide by hanging followed by family problems and borrowings. The reason for homicide was unknown in 12 cases of strangulation. In the remaining 6 cases cause was revenge. In drowning cases 64 cases are accidental and in 20 cases the reason for death was unknown. In drowning 13 victims commit suicide due to family problems. It was elicited from the history that personal reasons (136 out of 254 cases) like failure in the examinations, psychiatric problems, long time illness etc. were the most common reasons for suicide by hanging followed by family/domestic problems (41 cases), borrowings (23 cases) and extramarital affairs ( 7 cases). In 44 cases the reasons for suicide with hanging were not known and 3 victims were hanged accidentally during play. These findings are consistent with findings of Patel Ankur P et al. ${ }^{6}$

\section{Conclusion}

In present study, suicidal hanging and accidental drowning seems to be major proportions of violent asphyxial deaths. Both these manners of deaths indicate frustration and carelessness on part of population which are preventable and needs to be rectified on urgent basis. A comprehensive programme is needed to identify causative factors and prevention of suicidal behaviors. Prevention strategies for drowning should be comprehensive and include multiple aspects like removal of hazard by using modern engineering technologies, tough laws to enforce prevention and increase awareness among individuals to understand risk.

\section{Conflict of Interest: Nil.}

\section{References}

1. Reddy $\mathrm{K} \mathrm{S} \mathrm{N}$ : The essential of forensic medicine and toxicology, K. Sugunadevi, 28th edition 2009; 299-333.

2. Accidental\& Suicidal Deaths in India-2013 NCRB. Ministry of Home Affairs. Govt. of India. Accessed through website http://ncrb.gov.in 
3. Azmak D. Asphyxial deaths: a retrospective study and review of the literature. Am J Forensic Med Pathol. 2006;27(2):134144.

4. Gurudut KS, Ajaykumar S, Hareesh S Gouda, Analysis of Fatal Cases of Mechanical Asphyxia at Belgaum, Karnataka. $J$ Forensic Med Toxicol. 2011;28:51-53.

5. Amandeep Singh, Gorea RK, Dalal JS, Thind AS, Deepak Walia. A Study of Demographic Variables of Violent Asphyxial Deaths. J Punjab Acad Forensic Med Toxicol. 2003;3:22-25

6. Patel-Ankur P, Bhoot-Rajesh R, Patel-Dhaval J, Patel Khushbu A. Study of Violent Asphyxial Death. Int J Med Toxicol Forensic Med. 201 3;3(2):48-57.

7. Gupta Ved Prakash, Mahanta P.A Statistical Analysis of Asphyxial Death Cases in Medico-Legal Autopsy. IJHRMLP, 2016;2(2):86-89.
8. Lalwani S, Sharma GASK. Pattern of violent asphyxial deaths in South Delhi: A retrospective Study. Indian Med Gazette. 2004;258-261.

9. Srinivasa Reddy P, Rajendra Kumar. R, Rudramurthy. Asphyxial Deaths at District Hospital, Tumkur -A Retrospective Study. J Indian Acad Forensic Med. 2012;34(2).

10. Chaurasia N, Pandey SK, Mishra A. An Epidemiological Study of Violent Asphyxial Death in Varanasi Region (India) a Killing Tool. J Forensic Res. 2012;3:174.

11. Singh Gambhir O. A study of violent mechanical asphyxial deaths in homicide. J Forensic Med Toxicol. 2008;25(2):34-35

How to cite this article: Singh T K, Agarwal A, Gupta $\mathrm{R}$, Sharma V. A study of demographic variables of violent asphyxial deaths in Agra region. Indian J Forensic Community Med. 2018;5(4):223-226. 